*Now available for the first time in a British Edition

\title{
Lexical Aids for Students of New Testament Greek
}

\author{
BRUCE M. METZGER
}

This long-standing and wide-selling book, which for more than thirty years has proved itself an indispensable aid to American students of New Testament Greek, is now available for the first time in a British edition.

Lexical Aids for Students of New Testament Greek makes use of the principle of associative learning by supplying, after the English definitions of Greek words, such English derivatives as may be of assistance in remembering the meaning of the Greek vocabulary. The Greek words in the list have been selected and arranged in accordance with their frequency of occurrence in the New Testament.

Part II exhibits the family relationships between words of frequent and those of less frequent occurrence. After a student has become acquainted with a minimum working vocabulary of words that occur many times, he can make more rapid progress in acquiring a larger vocabulary by learning such additional words as resemble in general meaning and form those he already knows.

'In successive editions of Professor Bruce Metzger's Lexical Aids immense learning, accuracy and simple clarity have for many years combined to give the learner expert guidance in doses measured to his capacity. . . It is hard to imagine anything better.'

C.F.D. Moule, Emeritus Lady Margaret Professor of Divinity, University of Cambridge

'Professor Bruce Metzger's Lexical Aids . . . is a "must" for the beginner in New Testament Greek. Its graded lists of words . . lays the foundation of a good working vocabulary, because it is such a well-worked vocabulary of the New Testament writers.'

Matthew Black, Emeritus Professor of Biblical Criticism, University of St. Andrews

Price: $£ 2.95$ (paperback) 112 pages

ISBN 0631126058

\section{BASIL BLACKWELL PUBLISHER, OXFORD}

*North American purchasers should continue to order from Alec R. Allenson, Bookseller, Geneva, Alabama 36340, U.S.A. 


\section{NOTES FOR GONTRIBUTORS}

Contributions and editorial correspondence should be sent to one of the editors: Rev. Dr A. I. C. Heron, New College, Mound Place, Edinburgh EHI 2LX; Rev. Dr J. Houston, University of Glasgow, 3 Southpark Terrace, Glasgow GI $28 \mathrm{QQ}$ or to Scottish Academic Press Ltd., 33 Montgomery Street, Edinburgh EH7 5JX.

Submission of an article is taken to imply that it has not previously been published in English, or is not being considered by another journal for publication in English. In the interests of authors, copyright is normally assigned to the Scottish Academic Press. The average length of articles is 5000 words. Although longer articles are accepted, those in excess of 10,000 words cannot be considered.

Contributions (articles and reviews) should be clearly typed in double spacing, and on one side of the paper only. The rule about double spacing applies also to footnotes, which should be used sparingly. Cross-references within the article offered should not be included.

Notes for the editors and instructions for the printer should be attached on separate sheets. Contributors should keep one copy of the typescript for use in correcting proofs.

Contributors from the United States may use U.S. spellings. Greek and Hebrew words need not be transliterated. Capitalisation should be kept to a minimum; and in particular should not be used in pronouns referring to the Deity.

First proofs of articles and reviews may be read and corrected by contributors, and should normally be returned to the organising editor within ten days of receipt. Correction should be confined to errors of the printer. More extensive correction can be made only with the concurrence of an editor. No proofs of reviews will be sent.

Contributors of articles and article reviews (but not of reviews) receive Io free offprints. Extra copies may be bought according to an agreed scale of charges, provided that these are ordered at the time of returning corrected proofs.

\section{PERMISSIONS}

For permission to reproduce material from Scottish Journal of Theology please apply to the Scottish Academic Press Ltd., 33 Montgomery Street, Edinburgh EH7 5JX. 


\section{SCOTTISH JOURNAL OF THEOLOGY \\ VOLUME 34 No. 1}

\section{CONTENTS}

The Limits of Pluralism

by Professor H. F. Woodhouse

Christian Nurture and Critical Openness

by $\mathrm{DR}_{\mathrm{R}} \mathrm{JOHN}$ M. Hull

Some Reflections on the Identity of $\dot{\epsilon}^{\prime} \boldsymbol{\omega}^{\prime}$ in Romans 7: 14-25 by DR Brice L. Martin

Hans Urs Von Balthasar and the Rehabilitation of St Anselm's

Doctrine of the Atonement

by Professor Glenn W. Olsen

Hume on Evil

by Professor Julian Wolfe

\section{REVIEWS}

wiLмот: Whitehead and God,

Prolegomena to Theological

Reconstruction

GUNTON: Becoming and Being:

The Doctrine of God in Charles

Hartshorne and Karl Barth

MACKEY: Jesus the Man and the

Myth: A Contemporary

Christology

CUNLIFFE-JONES: A History of

Christian Doctrine

BRAY: Holiness and the Will of

God. Perspectives on the

Theology of Tertullian

WENHAM: The Book of Leviticus
COGGINS AND KNIBB: The First and Second Books of Esdras:

71 The Cambridge Bible

Commentary

84

CRANFIELD: A Critical and

Exegetical Commentary on the Epistle to the Romans IX-XVI and Essays

Lüdemann: Paulus, der

Heidenapostel I: Studien zur

78 Chronologie

BaILey: Biblical Perspectives on 80 Death 9 I

81 STEIN: Ministers for the 1980 s

(C) Scottish Academic Press Ltd. 1981

Printed in Great Britain by Clark Constable Ltd., Edinburgh 